\title{
Correction to: Progesterone receptor membrane component 1 regulates lipid homeostasis and drives oncogenic signaling resulting in breast cancer progression
}

Hannah Asperger ${ }^{1}$, Nadia Stamm¹, Berthold Gierke², Michael Pawlak², Ute Hofmann³, Ulrich M. Zanger ${ }^{3}$, Annamaria Marton ${ }^{4}$, Robert L. Katona ${ }^{5}$, Andrea Buhala ${ }^{4}$, Csaba Vizler ${ }^{4}$, Jan-Philipp Cieslik ${ }^{1}$, Zaklina Kovacevic ${ }^{6}$, Des R. Richardson ${ }^{7}$, Eugen Ruckhäberle ${ }^{1}$, Dieter Niederacher ${ }^{1}$, Tanja Fehm ${ }^{1}$, Hans Neubauer ${ }^{1 *+}$ and Marina Ludescher ${ }^{1 \dagger}$

\section{Correction to: Breast Cancer Res (2020) 22:75 https://doi.org/10.1186/s13058-020-01312-8}

After publication of the original article [1], the author reported that the 12th and 13th authors, namely Zaklina Kovacevic and Des R. Richardson, were accidently omitted. Both these authors have now been added to the author group and are now presented correctly.

\section{Author details}

${ }^{1}$ Department of Obstetrics and Gynecology, University Hospital and Medical Faculty of the Heinrich-Heine University Duesseldorf, Life Science Center, Merowingerplatz 1A, 40225 Düsseldorf, Germany. ${ }^{2} \mathrm{NMI}$ TT Pharmaservices, Protein Profiling, Reutlingen, Germany. ${ }^{3}$ Dr. Margarete Fischer-Bosch Institute of Clinical Pharmacology and University of Tübingen, Stuttgart, Germany. ${ }^{4}$ Institute of Biochemistry, Biological Research Centre, Szeged, Hungary. ${ }^{5}$ Institute of Genetics, Biological Research Centre, Szeged, Hungary. ${ }^{6}$ School of Medical Sciences, Faculty of Medicine and Health, Medical Foundation Building, University of Sydney, Sydney, New South Wales 2006, Australia. ${ }^{7}$ Centre for Cancer Cell Biology and Drug Discovery, Griffith Institute for Drug Discovery, Griffith University, Brisbane, Queensland 4111, Australia.
Published online: 28 January 2021

\section{Reference}

1. Asperger $\mathrm{H}$, et al. Progesterone receptor membrane component 1 regulates lipid homeostasis and drives oncogenic signaling resulting in breast cancer progression. Breast Cancer Res. 2020;22:7. https://doi.org/10.1186/s13058020-01312-8.

The original article can be found online at https://doi.org/10.1186/s13058020-01312-8.

* Correspondence: Hans.Neubauer@med.uni-duesseldorf.de

${ }^{+}$Hans Neubauer and Marina Ludescher contributed equally to this work. 'Department of Obstetrics and Gynecology, University Hospital and Medical Faculty of the Heinrich-Heine University Duesseldorf, Life Science Center, Merowingerplatz 1A, 40225 Düsseldorf, Germany

Full list of author information is available at the end of the article

C C The Author(s). 2020 Open Access This article is licensed under a Creative Commons Attribution 4.0 International License, which permits use, sharing, adaptation, distribution and reproduction in any medium or format, as long as you give appropriate credit to the original author(s) and the source, provide a link to the Creative Commons licence, and indicate if changes were made. The images or other third party material in this article are included in the article's Creative Commons licence, unless indicated otherwise in a credit line to the material. If material is not included in the article's Creative Commons licence and your intended use is not permitted by statutory regulation or exceeds the permitted use, you will need to obtain permission directly from the copyright holder. To view a copy of this licence, visit http://creativecommons.org/licenses/by/4.0/ The Creative Commons Public Domain Dedication waiver (http://creativecommons.org/publicdomain/zero/1.0/) applies to the data made available in this article, unless otherwise stated in a credit line to the data. 